\title{
Anísio Teixeira: a poesia da ação*
}

\section{Clarice Nunes}

Faculdade de Educação, U niversidade Federal Fluminense

U niversidade Estácio de Sá, Mestrado em Educação

\section{Introdução}

Agradeço à Diretoria da ANPEd o convite para celebrar a vida e a obra de Anísio Teixeira, na abertura da $23^{\mathrm{a}}$ Reunião Anual. Anísio Teixeira tem merecido, neste ano de tantos centenários de nascimento, como os de Gilberto Freire, Gustavo Capanema, Clemente Mariani, generosos e emocionados pronunciamentos nos mais diversos eventos em todo o país. Vários colegas têm produzido, sob diferentes ângulos e motivações, ensaios, artigos, livros, dissertações e teses sobre seu pensamento e sua ação. Sem ser a única a investigar sua contribuição para a educação brasileira, sinto-me privilegiada de compartilhar algumas reflexões que também muito devem à produção desses companheiros de jornada acadêmica. Minhas palavras são, portanto, fruto da interlocução com um trabalho que me ultrapassa, embora seja minha, nesta oportunidade, a responsabilidade e a honra de proferi-las.

* Conferência de abertura na $23^{\mathrm{a}}$ Reunião Anual da ANPEd Caxambu-MG, 24.09.2001
Sabem-se os nascimentos quando já foram sofridos. Assim que nasce, o sujeito empreende uma viagem rumo ao desconhecido, já que não sabe ainda quem é, mas vai descobri-lo nas suas respostas às provocações da própria existência. Na tensão entre a responsabilidade e ação daquele que se expõe ao mundo, no mundo, e o determinismo das forças que lhe são externas delineiase todo um espaço de manobra que leva à negociação das circunstâncias vividas. Essa concepção de negociação implica uma noção de intersubjetividade. Isto é, no cotidiano, o indivíduo raciocina e age pressupondo a existência de outros que, como ele, têm consciência, vontade, deveres, emoções. Nesse sentido, só posso fazer uma interpretação da trajetória de Anísio Teixeira colocando-o em relação dentro da sua própria geração e entre a geração de educadores que o antecedeu e o sucedeu. Também só posso compreender a obra de Anísio Teixeira entendendo que ela se confunde com o trabalho de seus colaboradores, de seus amigos, de todos os professores que, nas salas de aula, despertam a dignidade de que somos todos portadores, embora nem sempre a exerçamos. A sua obra é, para além dos resultados, um núcleo de reflexão que se abre incessantemente de forma origi- 
nal. É o sentido que dela fazemos, as representações que dela construímos e aonde palpitam os valores que abraçamos. Se a obra é o efeito de uma ação, o que me provoca é o que a move. O que me instiga é essa palpitação delicada que convida a nossa inteligência e a nossa sensibilidade a se empenharem uma vez mais, levantando perguntas sobre a atualidade desse educador e sobre a inspiração que sua contribuição pode ter para os educadores brasileiros contemporâneos.

\section{Anísio: sua vida é sua obra}

Anísio não nasceu educador. Tornou-se educador num processo laboriosamente construído, lapidado no diálogo com os diversos educadores que dentro dele transitaram, na intensa experiência dos exercícios espirituais realizados na juventude, nas reflexões suscitadas pelas viagens internacionais, nas fiéis amizades, como a que manteve com Monteiro Lobato e Fernando de Azevedo, na experiência da gestão pública da educação. Nesse sítio de vivências, povoado de lembranças pessoais, de forças vivas, quero lançar luz sobre as sombras e surpreender... os momentos de ruptura.

Os momentos de ruptura são constelações de sentido, repuxadas pelo elástico da tensão que, habitando o sujeito, se alonga no seu arco máximo, e obriga à opção entre render-se ao mundo ou afirmar-se em sua diferença no mundo. Identifico três momentos de ruptura na trajetória de Anísio Teixeira. Momentos de indecisão e dúvida. Momentos de crise que revelam um educador mais precário e perdido, menos crente e, por isso mesmo, muito menos preciso e mais apaixonado do que a literatura pedagógica nos fez acreditar. Momentos em que se descobre, que o homem apesar de não saber necessariamente ser feliz, pode apropriar-se do seu destino e olhar os seus problemas de frente. Momentos em que, sem resposta à angústia existencial, Anísio busca amparo no coração de outros homens.

\section{A primeira ruptura}

Anísio em sua juventude. Um rosto inaciano, olhando o mundo e vendo nele os sinais de Deus. Vinte anos de idade, tendo em suas mãos o passaporte de uma cul- tura humanista cristã que lhe permitiu a entrada na discussão dos mais diversos temas sociais, culturais, políticos e literários. Capaz de manejar a retórica como instrumento de poder, invenção e cultura. Formado advogado à contragosto. Congregado mariano, ávido pelas leituras filosóficas e piedosas: Santo Inácio, Antonio Vieira, São Tomás de Aquino. Admirador da monarquia. Filiado à tradição da restauração da Igreja católica. Alguém que interiorizou uma visão hierarquizada dos homens e considerava a família como instituição modelar da sociedade. Defensor de uma concepção elitista e seletiva do ensino.

Militante do movimento católico no início da década de vinte, Anísio Teixeira estava, nesse momento, ideologicamente próximo de Jackson de Figueiredo, Alceu Amoroso Lima e Plínio Salgado. Ao assumir o comando da Inspetoria Geral do Ensino, em 1924, na cidade de Salvador, Anísio viveu o cargo com fervor oligárquico e como um instrumento que tentava ampliar a área de influência da Igreja dentro do Estado. Espremido entre as aspirações da autoridade religiosa e as da autoridade paterna resistiu ao sacerdócio e à carreira de político profissional. Viajou para a Europa e Estados Unidos. Por força do cargo que ocupava entrou, pela primeira vez, em contato com uma literatura pedagógica e um sistema público de educação que não conhecia. Em oposição à cultura, à organização, à competência docente dos colégios nos quais estudara, deparou - em sua cidade e em seu estado natal - com a pobreza de recursos humanos e materiais, a dispersão e a desarticulação dos serviços educativos, o despreparo do professor, a imoralidade, a corrupção e a acomodação dos poderes públicos, alimentando a ineficiência da máquina estatal.

Foi um impacto para a sua sensibilidade! Essa vida, que acolhemos em nossas palavras, foi sacudida nos seus fundamentos. Não podemos dar conta do rodamoinho de emoções, provocado pelo contato com a civilização moderna e também pelos pequenos acontecimentos do cotidiano que solaparam a sua confiança na Igreja e o levaram a abdicar do sacerdócio, pelo qual se sentia predestinado. Anísio Teixeira fez a travessia do seu primeiro deserto: o deserto da fé, quando abdicou de uma religião que lhe dava segurança, mas que também não dava resposta às suas mais vivas inquietações. 
A passagem pelo Teachers College de Colúmbia, no final dos anos vinte, foi vivida com uma intensa carga afetiva, uma experiência de conversão pelo avesso. Numa dimensão laica Anísio reviveu situações que conhecera no "mundo dos colégios jesuítas", o que o empurrou a reinterpretar a realidade e produziu aos seus olhos e aos olhos dos outros uma ruptura biográfica que acentua o antes e o depois da estadia nos Estados Unidos. Adotou Dewey como sua plataforma de lançamento para o mundo, como viga mestra para compreender o que se passava na sociedade norte-americana. Escolhera um crítico contundente dos impasses da democracia norte-americana, um colaborador direto de instituições instaladas no meio da população pobre e imigrante com objetivos filantrópicos e educativos, um pensador que denunciava, aos Estados Unidos, que a ameaça da democracia não estava fora do país, mas dentro dele, nas atitudes pessoais e nas instituições.

Escolher John Dewey, de quem seria o primeiro tradutor no Brasil, era optar por uma alternativa que substituiu os velhos valores inspirados na religião católica e abraçados com sofreguidão. Era apostar na possibilidade de integrar o que, nele, estava cindido: o corpo e a mente, o sentimento e o pensamento, o sagrado e o secular. Era abrir o seu coração para o pensamento científico, apostando na crença de que o enraizamento e as direções da mudança social a favor da democracia estão postas na infância. O pragmatismo deweyano forneceulhe um guia teórico que combateu a improvisação e o autodidatismo, permitiu-lhe operacionalizar uma política e criar a pesquisa educacional no país.

As marcas dessa ruptura se evidenciaram nos deslocamentos que operaram na sua vida e nas novas idéias que horrorizaram alguns dos seus amigos mais íntimos que passaram a vê-lo então como um baiano americanizado. Mas essa imagem não era só dos seus amigos baianos. Alguns rapazes de São Paulo, que viriam a ser seus colaboradores nos anos trinta, no Distrito Federal, também construíram dele essa imagem que reconheceriam, um pouco envergonhados, ser equivocada. Ao visitar a Universidade de Colúmbia, em 1935, Lourenço Filho, refazia a imagem do amigo e dizia, em carta: "verifico que (em aspectos sociais e do pensamento) você é menos americano do que eu próprio supunha" (Atc 29.11.01, doc.15, CPDOC/FGV). Na volta da sua segunda viagem aos Estados Unidos, Anísio enfrentou o problema da coerência: ou modificava sua realidade ou mudava as relações com ela mantidas. Separou-se física, afetiva e mentalmente daqueles que com ele coabitaram o universo simbólico anterior. Sai da Bahia e refaz a vida na capital da República. Certas amizades cederam lugar a outras: encontrou Monteiro Lobato e Fernando de Azevedo. Ampliou suas leituras: William James, Bertrand Russel, Wells. Também Baudelaire, Proust, Dostoyewski e outros grandes talentos literários universais. Referindo-se ao ano de 1929, numa carta a Fernando de Azevedo, do início dos anos sessenta, afirmava: "Tenho a impressão que foi nesse ano que me encontrei comigo mesmo" (Vidal, 2000, p. 132).

O rompimento com a Igreja não significou a liberação das marcas da pedagogia inaciana na sua personalidade. Às vésperas da sua morte, já no ano de 1971, comentava com Fernando de Azevedo: "Com religião, ou sem religião, a realidade é todo esse impenetrável mistério, de que não há saída se não por essas pequenas frestas abertas ao espírito humano" (Vidal, 2000, p. 155). "Guardei de minha formação religiosa o sentimento de que viver é servir e nada mais esperar do que o conforto desse possível serviço" (Vidal, 2000, p. 152). Ao final dos anos vinte esse serviço ganharia uma direção nova. Dentro dele separaram-se definitivamente a Igreja e o Estado. Emergia, na luta dolorosa entre seus antigos sentimentos de fidelidade ao divino e às autoridades constituídas, a liberdade de pensamento e de expressão de si mesmo no mundo. Essa defesa pauta a sua conduta, pelo árido caminho da tolerância. Motiva seu desejo de exercer a pedagogia como bem de convivência, que não constrange ninguém a optar por uma idéia sobre a qual não tem clareza. É a questão de fundo de um projeto de recriação da cultura que atravessa todas as classes sociais. É a realocação da fidelidade, não mais aos dogmas de qualquer espécie, sejam eles religiosos ou científicos, mas à dança da própria vida. A fé incorporava a dúvida. A liberdade de pensamento acarretou a liberdade de opinar, de crer. Permitiu-lhe revolver vários aspectos contraditórios de si mesmo. Dialético, sem ser marxista! 


\section{A segunda ruptura}

Eis Anísio em sua mesa de trabalho, que é também uma mesa de existência à serviço da educação. Redige o programa do Partido Autonomista do Distrito Federal. Estamos no mês de fevereiro de 1935. Na introdução desse programa aponta a necessidade do Estado assumir o papel regulador da distribuição de bens, denuncia o fracasso da fórmula personalista das organizações partidárias nacionais. Apresenta o prefeito Pedro Ernesto como liderança confirmada pelo voto popular, pela primeira vez na história da cidade, destacando o sentido radical da sua obra pública, obra que ajudou a construir.

Dispara críticas: às organizações políticas liberais, que não percebiam a necessidade de homogeneidade $\mathrm{e}$ coesão, aos extremistas de esquerda e aos extremistas de direita que, no seio das suas organizações, tornavamse pequenos sacerdotes ativos e operantes dos ideais e das soluções do seu partido, todas essas atitudes contrárias à formação de uma mentalidade aberta.

Propõe um partido para o qual a primeira necessidade é a difusão da cultura e do esclarecimento público dos problemas brasileiros e de suas possíveis soluções. Todo esse esforço acompanhado de rigorosa liberdade de palavra e de imprensa. O partido revolucionário, como ele o chamava, mas que também foi denominado de Partido Autonomista do Distrito Federal, não precisaria da censura ou do segredo. As idéias deveriam triunfar pelo seu mérito. $\mathrm{O}$ que este partido procuraria garantir era um padrão mínimo de educação e de informação, a defesa e manutenção da saúde e os direitos sociais elementares da honra, como o da subsistência, trabalho e conforto relativo (AT pi 37/46.00.00, $\mathrm{CPDOC/FGV).}$

Por que Anísio escreveu um programa partidário? Para defender uma obra arduamente construída e que criara, na cidade do Rio de Janeiro, um sistema de ensino municipal que ia da escola primária à universidade $\mathrm{e}$ que corria sérios riscos numa conjuntura na qual o pensamento autoritário crescia dentro do Estado e na própria sociedade, onde as posições políticas se radicalizavam, onde se gestava, como o ovo da serpente, a ditadura varguista. Paschoal Lemme não compreendia a indiferença de Anísio quando lhe alertou sobre a conveniên- cia de não opor qualquer obstáculo ao pleno cumprimento do dispositivo constitucional, elaborado por Francisco Campos, que garantia a presença do ensino religioso nas escolas públicas. Chegou a comentar que Anísio parecia não se preocupar com a formidável onda que ia se agigantando contra ele, movida pelas incompreensões, ignorância e má-fé. Má-fé que rotulava sua obra de anárquica, dissolvente dos costumes e desagregadora da sociedade (Lemme, 1988, p. 143-147).

Essa "obra anárquica", como taxavam os opositores de Anísio Teixeira, contou com uma equipe que reuniu grande número de colaboradores dos mais distintos matizes ideológicos: católicos, liberais, comunistas, pensadores de direita e pensadores de esquerda. Como foi possível reunir pessoas tão diferentes numa obra comum? Só podemos compreender essa possibilidade se visualizarmos o Estado sinalizando seu desejo de introduzir o Brasil na modernidade. As portas se abriram. Urgia entrar e tentar. A habilidade coordenadora de Anísio lidou com a tensão entre inflexões que, de um lado, empurravam as realizações da sua gestão para uma abertura real das chances educativas e, de outro, para a formulação de pesquisas e instrumentos que partiam de uma concepção autoritária das classes populares.

A escola primária, a escola técnica secundária e o ensino de adultos se expandiram e melhoraram a sua qualidade. A escola técnica foi um interessante pomo de discórdia, não apenas porque reuniu, pela primeira vez no país, num curso secundário, a cultura geral aos cursos técnicos profissionais, antes existentes apenas ao nível primário, mas também porque valorizou os seus diplomas, além de introduzir a participação dos estudantes, organizados em conselhos, na gestão escolar. As bibliotecas, sobretudo a biblioteca infantil, grande novidade, e as bibliotecas de classe dinamizaram a pedagogia. A rádio educativa colocava o governo municipal falando diretamente aos corações e mentes das famílias cariocas. O professor primário foi prestigiado pois, pela primeira vez no país, sua formação ocorreu em nível superior na então recém-criada Universidade do Distrito Federal. A educação foi instituída como área de investigação acadêmica. Ao mesmo tempo, porém, sob sua gestão, produziam-se pesquisas no Instituto de Pesquisas Educacionais, como as de Arthur Ramos, que defen- 
diam o controle brando das crianças, ou ainda, aplicavam-se, nas escolas primárias, apesar das suas discordâncias, os testes classificatórios de alunos.

Anísio Teixeira participava da mentalidade da sua época e acabou endossando o papel disciplinador da escola sobre a cidade, ao lidar com a heterogeneidade das classes populares e de suas crianças dentro delas, mas não o fez, como alguns de seus colaboradores, de forma a identificar a heterogeneidade como carência de atributos intrínsecos do sujeito pobre. Ele deslocou a carência do indivíduo para a omissão dos governos na direção da reconstrução das condições sociais e escolares. Não considerou as classes populares urbanas como obstáculos sociais e políticos e por esse motivo defendeu a educação como instrumento de superação de uma carência que não é do indivíduo, mas da cultura erudita que lhe faz falta. Pode perceber que a desigualdade entre as pessoas não estava dada. Era feita.

A obra comum da equipe de Anísio não impediu as divergências e as críticas aos seus colaboradores e até mesmo aos amigos mais queridos. Críticas que despontam pelas margens ou, como ele preferia dizer, em pontos menos exatos. Ao comentar, no começo dos anos trinta, o bem-sucedido livro de Lourenço Filho Introdução ao estudo da Escola Nova, Anísio apontou a sua visão rígida da técnica pelo esvaziamento de aspectos substantivos do pensamento filosófico. Ao considerar a avaliação da aprendizagem como uma atitude inerente a qualquer iniciativa escolar, ele abriu espaço para recolocar a avaliação enquanto prática suscetível de crítica no seu processo mediante os seus resultados, relativizando o valor dos testes tão defendidos por Lourenço Filho e Isaías Alves. Já nos anos quarenta, ao comentar, a obra Sociologia Educacional, de autoria de Fernando de Azevedo, afirmava numa belíssima carta que "a educação é sobretudo um sentido". Perguntavase: "e este sentido é arbitrário ou imposto pelas instituições? (...)". Afirmava: "Creio que em educação sempre haverá mais necessidade de filosofia do que de ciência (...) a educação é, sobretudo, uma arte que progride como progride a música" (Vidal, 2000, p. 43). Anísio nunca abandonou a concepção da educação como uma prática atravessada pela ciência e, ao mesmo tempo, pela arte. É pela filosofia e pela arte que relativiza o peso da ciên- cia na educação. É pelo seu amor a ambas que, mesmo tendo escrito um programa partidário no momento em que sua obra estava ameaçada, se afasta dos partidos. Ele recusava a noção de ordem, lealdade, hierarquia e o desprezo pela discussão teórica, comuns nas hostes partidárias de então. Esses aspectos criavam, em Anísio, uma antipatia por qualquer filiação, mas não impediram que ele convidasse homens de partido, comunistas como Leônidas Rezende e Edgardo Castro Rebelo, para ingressarem nos quadros da Universidade Federal. Essa atitude de Anísio não era isolada. Nesse caso, ele se aproximava de artistas e escritores que defendiam explicitamente sua independência de criação e a usavam para justificar a sua não-adesão a partidos políticos de qualquer espécie. Essa não adesão convivia com uma certa simpatia militante por algumas idéias comunistas, da qual partilhavam Carlos Drummond de Andrade e Paschoal Lemme (Andrade, 1983, p. 9). Jorge Amado, eleito deputado do Partido Comunista Brasileiro, por São Paulo em 1945, dedicaria a Anísio Teixeira, a quem considerava o amigo das crianças, o seu livro Capitães da Areia.

À medida que, em meados dos anos de1930, a modernização autoritária se firmou, Anísio Teixeira catalizou a perseguição de católicos e pensadores autoritários. Sua gestão foi avaliada como uma estratégia de oposição dentro da estratégia oficial e, como tal, foi combatida e interrompida. Os católicos invadiram a prefeitura e controlaram os serviços educativos. Vencera o projeto repartido de educação: para o povo, uma educação destinada ao trabalho e para as elites, uma educação para usufruir e exercer a cultura. Anísio opusera ao nacional, o democrático entendido menos como conjunto de mecanismos de participação dos indivíduos na sociedade política e mais como mecanismos de democratização da sociedade civil (Warde, 1984, p. 105139). A reforma por ele conduzida empurrou a escola para fora de si mesma, ampliando sua área de influência na cidade. Atravessou o espelho da cultura européia e norte-americana, articulando o saber popular ao acadêmico. Retirou o problema da educação da tutela da Igreja e do governo federal. Todos esses aspectos marcam o caráter polêmico da sua gestão, graças à sucessão de conflitos que se criaram em vários níveis: no nível governamental, no nível ideológico e no interior das próprias escolas. 
Anísio Teixeira atravessou o seu segundo deserto: o da solidão. Como afirma Renato Janine Ribeiro, no posfácio ao livro de Carlo Ginzburg, $O$ queijo e os vermes, "nem toda confissão é uma vitória da tortura; porque às vezes a pior tortura é ter a voz silenciada" (1987, p. 241). A opressão política calou a voz de Anísio, dos seus colaboradores, dos seus admiradores. A memória da formidável obra pública que ele e sua equipe de trabalho empreenderam foi apagada. Escrevendo a Anísio, em meados dos anos quarenta, Monteiro Lobato rememora:

Lembro-me quanto te vi no Rio de Janeiro, (perseguido) pela polícia, escondido pelos amigos como um grande criminoso - e naquela ocasião também chorei. To whom the bells toll? Todos estávamos implicitamente perseguidos, foragidos, escondidos com você (...) Dez anos passou você caminhando como minhoca por baixo da terra escondido da Reação Triunfante, mas caminhando sem o saber. (Vianna \& Fraiz, 1986, p. 101)

Na mesma mesa em que Anísio escrevera o Programa do Partido Autonomista do Distrito Federal, Francisco Campos escreveria a Constituição do Estado Novo. $\mathrm{O}$ volume e o teor das cartas recebidas por Felinto Müller, em meados dos anos de 1930, ávidas pelo combate e repressão ao comunismo, revelam que Anísio tinha razão quando escrevia à Hermes Lima mostrando a importância da formação da opinião pública no combate aos dogmas, aos medos, aos preconceitos e aos fanatismos de qualquer espécie (Nunes, 2000, p. 511). Tornara-se um trabalhador gasto e desmoralizado pelo fascismo brasileiro. Acusado de tapeador público por Everardo Backeuser. Denunciado nos subterrâneos do Serviço Secreto da Polícia varguista ao lado de estupradores, estelionatários e mandantes de homicídio. Viria a revanche? Mais traduções aconteceram. A família aumentou com os novos filhos que chegaram. Mineirou manganês no Amapá e vendeu carros em Salvador. Os tocos da sua obra, como profetizara Lobato, ficaram enterrados para brotar de novo. Em meados dos anos quarenta finalmente era reconhecido pela UNESCO, que o convidava para sua inserção na entidade como conselheiro do ensino superior.

Sua dura experiência nos anos da ditadura varguista não seria a única. De onde vinha a força para enfrentar a hostilidade contra a realização da educação popular e realizar o sonho de um país cidadão, humano e solidário? De todo o período de realizações dos anos trinta e o posterior silêncio a que foi submetido, Anísio carregou uma convicção, a de que as questões sociais eram manifestações da cultura e de que era preciso combater os problemas que a industrialização trazia. Afirmava:

\section{[...] com a industrialização desapareceu a integração entre o homem e o seu trabalho, que dividido e superdividido passou a ser esforço coletivo e impessoal. Depois, com o desenvolvi- mento do saber, também este passou a ser especializado e não oferecer senão algo muito reduzido de saber realmente comum. Com isso desfez-se a integração entre o homem e o saber. Com a democracia, por fim, entendida como processo de maior par- ticipação de cada indivíduo nos bens da vida, esses bens pas- saram a ser concebidos como bens materiais, únicos que eram possíveis ao acesso de cada indivíduo. E a democracia fez-se uma democracia de consumo, o homem se sentindo tanto mais importante quanto mais pudesse consumir (Teixeira, 00.00.00/ 17, CPDOC/FGV).}

Para ele a civilização da abundância estava exagerando a importância dos bens de consumo e não era neles que residia a felicidade humana. Essa tão acalentada felicidade só se concretizaria com a integração do homem ao trabalho e à cultura. Caberia ao Estado ser o principal promotor da escolarização e difusor da cultura junto às classes populares. Ao lado dessa convicção carregava também, na sua valise de peregrino, a incômoda questão que o acompanhou desde a juventude e que, já na maturidade, vislumbrava no seu ponto mais agudo: Qual a magnitude da pobreza brasileira? Aprendera, na primeira metade da sua vida, que a pobreza não é só a destituição dos bens materiais. É também a repressão do acesso às vantagens sociais. Não é só fome! É também segregação, degradação, subserviência, aceitação de um Estado avassalador e prepotente. A pobreza brasileira era também, e no mesmo grau de importância da pobreza material, a pobreza política. O seu contrário emergia no horizonte dos direitos humanos e civis: a cidadania organizada. 


\section{A terceira ruptura}

No dia 9 de abril de 1964, o reitor da Universidade de Brasília (UnB), Anísio Teixeira, o vice-reitor Almir de Castro, os professores e os funcionários foram surpreendidos por uma operação insólita: tropas do Exército e da Polícia Militar de Minas Gerais tomaram de assalto o campus. Era a primeira de outras duas invasões que ocorreriam em 1965 e 1968. Os policiais procuraram armas. Inspecionaram minuciosamente a reitoria, a biblioteca, todos os escritórios em todos os setores. Prenderam professores e estudantes. Anísio Teixeira é demitido do seu posto, ao lado de todo o Conselho Diretor da Fundação da universidade (Salmeron, 1999). A autonomia universitária é violentamente agredida. Essa agressão dispara uma campanha de difamação do trabalho até então desenvolvido com dificuldades, mas com muita dedicação e esperança, trabalho espezinhado por setores da imprensa que se aliaram ao regime militar sob os rótulos da irresponsabilidade, da indisciplina, da subversão, do atentado à doutrina da segurança nacional. Mais uma vez o Estado desqualificava a obra para que a sociedade lhe retirasse o apoio e, no enfraquecimento, a repressão pudesse agir: para aniquilar. De novo as lágrimas de Alcides da Rocha Miranda que, lembrando a UDF, chorava a UnB. De novo a perseguição, a prisão de intelectuais.

Anísio elaborou o anteprojeto da Universidade de Brasília à convite de Juscelino Kubitschek e de Clóvis Salgado, no momento em que também organizava o Plano Educacional de Brasília. Convidou Darcy Ribeiro para discutir sua proposta. Se não fosse esse gesto de Anísio, Darcy Ribeiro não teria participado da fundação da universidade. Polemizaram sobre a sua organização. Anísio, defendendo a tese de que a UnB deveria ser estruturada para operar apenas como centro de pós-graduação, destinado a preparar o magistério superior do país e Darcy contra-argumentando que, ao lado da pósgraduação, os cursos de graduação seriam indispensáveis (Ribeiro, 1978, p. 14). O processo de discussão da universidade passou, em 1960, pelo fórum da SBPC, especialmente instalado para discuti-la. Quando a universidade foi finalmente criada, já no governo de João Goulart, Anísio não aceitou o cargo de reitor que lhe fora oferecido. Assumiu a vice-reitoria da instituição para prestigiar Darcy Ribeiro e socorreu diversas vezes a universidade em seus momentos iniciais, através da transferência de verbas do Instituto Nacional de Estudos Pedagógicos, do qual era Diretor desde meados dos anos cinqüenta, para a Fundação Universidade de Brasília (Ribeiro, 1978, p. 33).

Anísio fez do INEP uma instância de condução da política educacional dentro do Ministério da Educação e Cultura, pelo manejo e destinação de verbas e pela criação de uma infra-estrutura para a pesquisa social e educacional no país que colocou, lado a lado, cientistas e educadores em projetos comuns através do Centro Brasileiro de Pesquisas Educacionais e dos Centros Regionais, que funcionaram em São Paulo, Recife, Salvador, Belo Horizonte e Porto Alegre. Através de convênios do INEP com as secretarias estaduais, o MEC se propunha a equipar escolas que ampliassem a escolaridade primária para seis anos, a construir centros de aperfeiçoamento docente. Com essas medidas, que canalizavam verbas públicas para instituições públicas, e a defesa do controle da formação do professor primário pelo poder público, através do exame de estado, ele irritou as instituições confessionais católicas e os deputados interessados no fornecimento de verba do INEP para a construção de escolas rurais transformadas em moeda de troca eleitoral.

Toda a grande polêmica provocada pelo livro $E d u$ cação não é privilégio no ano de 1957 - da qual a publicação do Memorial dos bispos gaúchos, solicitando a exoneração de Anísio Teixeira do INEP é uma conseqüência, dentre outras - colocou em xeque uma vocação pública num país de ferozes interesses privatistas. Mais uma vez Anísio catalisava a ira dos católicos que fizeram da Revista Vozes sua trincheira de luta (Nunes, 1994). Mas, ao polemizar contra a Igreja, Anísio acionava, através dos seus pronunciamentos, a opinião pública, os órgãos do legislativo, do executivo, a própria universidade e setores combativos da intelectualidade colocando em foco a necessidade da expansão e da qualidade de uma formação pública comum de todos os brasileiros. A luta agora se fazia no sentido de se contrapor aos interesses privatistas sobre a educação na Lei de Diretrizes e Bases. 
A capacidade de suportar a avalanche de críticas que recebeu, tanto nos anos trinta quanto nos anos cinqüenta, e que impressionava seus colaboradores diretos, era resultado visível da pedagogia da Companhia de Jesus. A arte de governo da Companhia talhou, nele, a indiferença inaciana, uma formidável resistência psicológica construída no embate dos exercícios espirituais, quando a alma atravessa suas noites escuras, e constrói uma profunda adesão aos valores sagrados. A educação para ele foi um valor sagrado. A indiferença inaciana, extremamente ativa e vigorosa nele, foi colocada a serviço da causa pública à qual se dedicou e que o levou não só a enfrentar lutas duras, mas também incluiu uma das mas belas realizações da educação popular no país, já no final dos anos quarenta: a conhecida Escola-Parque, ao lado das classes comuns de ensino, no bairro operário da Liberdade. De novo, uma escola feliz, que reunia às classes comuns de ensino as práticas de trabalho, artes, recreação, socialização e extensão cultural.

Nos anos de 1960, no entanto, sua trajetória foi novamente colocada à prova. A ditadura militar constrangeu a Universidade de Brasília e quebrou, como dizia Darcy Ribeiro, uma das coisas mais importantes que Anísio fizera no país: o centro brasileiro e os centros regionais de pesquisa. De novo se frustrava a tentativa de tornar a educação uma área de investigação acadêmica. O INEP foi desativado como agência de produção da pesquisa educacional, tornando-se, primeiramente, um órgão burocrático e depois uma agência financiadora de estudos e pesquisas na área. Algumas das suas publicações como Educação e Ciências Sociais foram suspensas e outras, como a Revista Brasileira de Estudos Pedagógicos, passaram a ter edição irregular. Os acervos documentais e bibliográficos, laboriosamente organizados pelo Centro Brasileiro de Pesquisas Educacionais, foram dilapidados.

Anísio Teixeira atravessou o seu terceiro deserto: o do ceticismo. Banido, suspeito, excluído. Respondeu à violência com o seu trabalho, o trabalho possível, como professor visitante em universidades estrangeiras, tradutor, conferencista, membro integrante do Conselho Nacional de Educação, idealizador do Instituto de Estudos Avançados em Educação (IESAE) no Rio de Janeiro. Numa carta que Anísio Teixeira escreve a Monteiro
Lobato, em janeiro de 1947, ele afirma: “[...] Os sonhos não se realizam sem que primeiro se armem os andaimes. E uma construção em andaimes pede imaginação e amor para ser compreendida (Vianna \& Fraiz, 1986, p. 104). Uma escola pública com um ensino básico de qualidade para todos, onde a pesquisa é assumida como componente do ensino, e em que os espaços e os tempos da educação sejam significativos para cada sujeito dentro dela. Uma escola bonita, moderna, integral em que o trabalho pedagógico apaixona e compromete professores e alunos. Uma escola que construa um solidário destino humano, histórico e social foi o grande sonho de Anísio Teixeira, para o qual procurou construir os andaimes.

A violência barrou suas iniciativas, mas não venceu a sua implacável denúncia de que a privação da educação torna impossível até a simples sobrevivência. Anísio estava convencido de que sem a qualidade cognitiva e psicossocial das experiências de conhecimento não existem vivências da esperança. $\mathrm{E}$ a escola, tal como ele e seus colaboradores pensaram, e concretamente criaram, pretendia instituir-se como organizadora da esperança em vidas humanas concretas. Mas a organização da esperança assusta, porque desestabiliza privilégios. Porque exige, sobretudo, a paciência dos recomeços.

Em toda a produção de Anísio Teixeira, nos seus quarenta anos de vida pública, o tema da democracia no âmbito da escola e fora dela foi decisivo e se impôs sobre outros temas, ganhando na sua obra, mas principalmente com a sua vida, uma entonação própria, distinta mesmo de outros intelectuais que colaboraram com os seus projetos ou se opuseram a eles. Do ângulo da educação popular, as construções escolares que edificou, tanto no Rio de Janeiro, quanto em Salvador, foram palco de uma expansão regulada tanto das atividades dos estudantis, quanto da sua comunicação interativa. Os espaços de aprendizagem na escola se ampliaram e diversificaram. Mas, e os alunos? Como os alunos percebiam essas novidades?

As escolas criadas por Anísio e a geração de educadores à qual pertenceu, tanto nos anos 30 quanto nos anos 50 e 60, não foram vistas pelos alunos que as freqüentaram como locais de confinamento. Pelo contrá- 
rio, constituíram a possibilidade de reapropriação de espaços de sociabilidade crescentemente sonegados às classes trabalhadoras pelas reformas urbanas que lhes empurravam para a periferia da cidade. Para muitos desses alunos, essas escolas foram a única abertura para uma vida melhor. Num belo depoimento registrado em Sous-venir de classe (memórias do curso de Política de Formação de Professores) uma ex-aluna discorre sobre a importância que o projeto de Anísio e seus companheiros de geração tiveram na sua vida de adolescente, na década de 60. Diz ela:

Se para o país a fábrica era a base do avanço, se dela vinha o sustento da família, na hora do jantar e da fiscalização de cadernos e boletins a fábrica era o dragão devorador de criancinhas que trocassem os livros pela brincadeira, pelos namoricos ou festas. Ninguém era obrigado a estudar. Mas se não estudasse, fábrica. E fábrica significava levantar ainda noite, embrulhar em jornal a marmita que passara a noite aberta para não azedar, coar o café, colocar na garrafa de guaraná com rolha de cortiça, enfiar-se numa pesada e puida roupa de frio, pendurar-se tiritando num trem e depois num ônibus, ficar oito horas de pé na frente de uma máquina, suportar o (chefe), ganhar pouco, não ter feriados nem férias, trabalhar 35 anos e morrer. Com sorte, casar com o colega do lado. Ou, a sorte grande, com o padeiro e ir para o tanque, cinco filhos, fogão e vassoura. Silvio Santos na TV, macarronada no domingo. E morrer. Sempre morrer. Talvez por isso meus poemas de adolescente falem tanto em morte. Progresso ou morte. Era esse o lema lá em casa. Uma casa de operários procurando dar o salto que o país = nação prometia. E todos nós acreditamos nisso. Sinceramente. Dedicadamente, cada minuto da vida daquelas décadas. Podia-se não ter carne ou leite, mas tinha livro e tinha que ler, nem que fosse com vela. Tínhamos que nos apropriar desse capital-saber que nos daria o passaporte para o progresso (Lagoa, 1995, p. 4).

Ainda narrando suas lembranças, escritas em meados dos anos noventa, ela acrescenta:

[...] a fábrica ficou lá atrás, mas o que ela representou na minha vida está sempre presente. Descobertas, aumentando meu respeito pela Escola Nova, sobretudo por Anísio Teixeira e pelos professores que se dispuseram a educar para o Brasil grande. Sem ele, sem eles, sem os que depois, em São Paulo (e, acres- cento eu, também no Rio de Janeiro, em Curitiba, Porto Alegre, Belo Horizonte, Recife, Salvador, Natal e tantas outras cidades brasileiras), deram seguimento ao projeto, mesmo que tenham cometido muitos erros, eu certamente não estaria aqui. E um sentimento de ter feito parte de algo grande, de um projeto de país, de um sonho. E não apenas alguém que se esforçou para fugir da fábrica. E entendi (continua ela), porque [...] não me convencia com o discurso crítico da esquerda contra a escola pública daquela época. A crítica estava torta. A escola pública entortou depois (idem, p. 18-19).

Do ângulo da formação dos intelectuais, a trajetória de Anísio Teixeira em defesa da universidade pública e de instituições públicas de pesquisa ou de financiamento à ela, como a CAPES - Campanha de Aperfeiçoamento do Pessoal do Ensino Superior, que sob a sua condução se transformou em órgão, tem implícita a convicção de que não há país capaz de sobrevivência digna sem instituições, sobretudo como a universidade, capazes de produzir conhecimentos e propor soluções próprias às questões que o afligem. Mas o que gostaria de enfatizar, na sua defesa do ensino e da pesquisa, e que geralmente não tem merecido suficiente destaque, é a liberdade de criação. Graças à uma interlocução ativa dentro do pensamento social brasileiro, com os nomes mais destacados da intelectualidade, Anísio colocou a educação em sintonia com os avanços das demais ciências humanas e sociais. Colocou-a também em permanente diálogo com a arte, concebida no sentido antropológico, como defendia Mário de Andrade e não no sentido monumental que the conferiu, por exemplo, o virtuosismo de Villa Lobos. Em Salvador, no final dos anos quarenta, elaborou o Projeto Educação pela Arte e fez construir, sob a liderança de Alcides da Rocha Miranda, um Centro Educativo de Arte Teatral, destinado à dança e à música (Salmeron, 1999, p. 45) No Rio de Janeiro manteve constante interlocução com Augusto Rodrigues e seus companheiros da famosa Escolinha de Arte do Brasil, que constituía, como afirmou em meados de 1970, uma das poucas e importantes inovações pedagógicas do país (Costa, 1994, p. 3).

O que se manifesta por trás e por dentro das rupturas apresentadas, dessas constelações de sentido presentes na obra de Anísio é a atualíssima questão da relação 
dos intelectuais com o poder, a tensão entre a competência e o compromisso assumido, o pretendido e o viável, a tradição e a invenção, a desagregação e a construção social.

\section{A obra de Anísio Teixeira como provocação}

Hoje, quando celebramos a presença viva de Anísio Teixeira na nossa memória, eu me pergunto se realmente podemos alcançar o significado de sua obra. A prudência me impele pelo menos a destacar a apropriação que podemos fazer das suas concepções no momento atual, o que pode sugerir alguns caminhos. Distinguia ele em Educação no Brasil, obra de 1969, presentes efervescentes e presentes estagnados. Nos primeiros o passado estaria vivo, entreabrindo o futuro. Nos outros o presente seria depreciado em nome de passado transformado em objeto de culto nostálgico e paralisante. Com lucidez, continuava: "Toda verdadeira crise humana é uma crise de compreensão do presente, (...) Cabe-nos (...) tornar o presente compreensível, a despeito das contradições, por intermédio do que chamamos cultura" (Teixeira, 1969, p. 367-385).

O centro da nossa crise atual é a violência encarnada nas instituições, com todas as suas múltiplas faces e perigos: na família, onde muitas situações revelam a desproteção de crianças, mulheres e idosos; na escola, espaço de discriminação, de exclusão de classe, etnia e gênero. No trabalho, urbano ou rural: a presença precoce da criança, os índices alarmantes de acidentes, o esvaziamento das organizações sindicais, a violação dos direitos e a desumanidade das relações, condições e processos de trabalho. Na política: a hegemonia da globalização financeira que reduziu o papel dos estados nacionais e o controle social democrático sobre o rumo do atendimento às necessidades fundamentais da pessoa humana, a recolonização latino-americana, a corrupção no trato da coisa pública.

A globalização econômica tem revelado a tirania do dinheiro e também da informação, o crescimento da miséria, a crise de identidades e a manutenção da injustiça social. Se o centro da crise atual é a violência que cresce, diante da ausência de sentido para se estar no mundo, o mais grave é o quanto ela está instalada den- tro de nós, em maior ou menor grau também impregnados pela cultura do consumismo, pela atitude de negação ou resignação diante do sofrimento alheio, banalizando-o, apreendendo-o de forma dissociada da injustiça que o acarreta.

A crise do presente na educação contemporânea não é apenas problema dos outros, que não a possuem, mas de todos, sobretudo dos próprios educadores. "A pedagogia atua apenas sobre o humano. A ela interessa constituir aquele grupo humano com o qual qualquer projeto futuro pode contar" (Gonzaga Teixeira, 2000, p.106). Aqueles que realmente se dedicam e acreditam. A utopia está justamente aí, nesse sentir-se. Nessa perspectiva, a utopia não tem alvo externo. Enraíza-se nesse fazer parte, nessa companhia, na socialização das nossas experiências mais íntimas tanto na escola quanto no trabalho (idem, p. 105-107 e 128). Nessa socialização de experiências, a negação e a recusa ao reconhecimento do nosso sofrimento no trabalho e na escola constitui importante obstáculo ao reconhecimento do sofrimento dos que estão sem trabalho e sem escola (Dejours, 1999, p. 46). É possível que se alegue que esse sofrimento não é algo novo. Sempre existiu. De fato, o novo não está na iniqüidade, na injustiça ou no sofrimento imposto ao outro. Está no fato de que hoje essa imposição pareça razoável, justificada. A novidade está, como denuncia Christophe Dejours, na banalização das condutas injustas que constituem a trama (Dejours, 1999, p. 139). Como pertencer, sem dialogar com o mundo que nos cerca? Como dialogar, sem realizar a crítica ao nosso próprio modo de pensar? Anísio dizia, e cito de memória, que o pensamento é o ato mais vigiado de todos.

A violência internalizada, mas velada, de confinarmos idéias ou pessoas a julgamentos e rótulos antecipados e definitivos, vítimas de nossos preconceitos e de avaliações equivocadas e parciais sobre as ações humanas precisa ser combatida. "A utopia não aceita seres humilhados, diminuídos, amputados. A pedagogia mais próxima da utopia é a que coloca à disposição de cada ser humano toda a cultura humana" (Teixeira, 2000, p. 137). "É pela pedagogia que a utopia atua sobre a política e a economia" (Teixeira, 2000, p. 6). Nessa direção, a obra de Anísio Teixeira é um convite para que resgatemos o sentido da qualidade da educação no que 
tem de substantivo, ou seja, enquanto conjunto de transformações sociais que visam eliminar privilégios, hierarquias e desigualdades, o que se faz decisivo e urgente, na medida em que a face menos explícita da autonomia que a escola brasileira hoje goza quanto ao seu projeto pedagógico, garantida pela atual Lei de Diretrizes e Bases (1996), é a que institui os estabelecimentos de ensino como alvo de concorrência e escolha dos pais. Essa escolha, no entanto, está condicionada pela desigualdade no acesso aos recursos materiais e simbólicos, provocando diferentes escolarizações. A afirmação neoliberal de uma educação de qualidade oculta o fato de que a alguns está destinada uma educação de maior qualidade que a outros (Silva, 1996, p. 83).

Apenas o senso de futuro permite uma apreciação mais refinada do real com o intuito de descortinar as possibilidades. Nossas dificuldades se instalam no largo caminho das mediações. O discurso neoliberal é, sem dúvida, um processo poderoso, mas não podemos esquecer que as políticas globalizadoras, presentes num mesmo quadro discursivo e mediante projetos semelhantes em vários países, não são propriamente idênticas, pois inexiste - e a análise histórica mostra isso - correspondência perfeita entre as reformas pretendidas e as executadas, mesmo quando as opções políticas se encontram subordinadas à orientação global. $\mathrm{O}$ peso das tradições culturais nacionais, os constrangimentos próprios de cada contexto de escolarização, o trabalho de reinterpretação dos atores no campo escolar em cada nível, desde o mais alto centro de decisão até a sala de aula não podem ser menosprezados. Talvez fosse oportuno considerar não propriamente a globalização das políticas educacionais, mas a sua hibridização (Zanten, 2000).

O que se espera da pesquisa em educação nesse momento é que transforme em problema o que é tomado como fato estabelecido, distinguindo expectativas de comportamentos (políticos, sociais, culturais e pedagógicos) de desempenhos efetivos, sacudindo a atitude acomodada, pouco ou nada crítica, dedicada exclusivamente a aprimorar o que já existe, identificando em nossa prática compartilhada os consensos que entravam o avanço da produção do conhecimento daqueles que o facilitam. Espera-se da pesquisa a crítica como dispositivo que avalia as alegações de conhecimento e que se transforma, no plano da política, num dispositivo prático, mas não estreito, de solução de problemas e de neutralização da ação perniciosa dos maus governantes. Cabe à pedagogia da pesquisa recusar o monopólio do pensamento crítico em qualquer instância e difundir atitude crítica para toda a vida social. Assim entendo a militância do pesquisador.

Resgatemos de Anísio, nesse momento, o diálogo entre a ciência e a arte, que é também o diálogo entre a demonstração e a transfiguração, a intuição poética e o discernimento crítico, as emoções e o pensamento. Que é também a possibilidade de percepção do mundo em sua gloriosa novidade. Que desperta o entusiasmo criativo e ajuda a elevar o homem a um nível mais alto de existência. Endosso a perspectiva de que a união da cultura artística e da cultura científica, num mundo de degradação ambiental, social e psíquica, é o eixo de uma nova educação.(Costa, 1994, p. 17) É um diálogo que não tenta a derrota do oponente, mas a expansão do seu próprio ponto de vista. É um diálogo que amplia a experiência estética e que coloca em destaque a nossa genuína capacidade criativa, não só no nível do resgate da beleza, que faz parte da existência humana, mas também nas suas "implicações ético-políticas, porque quem fala em criação, fala em responsabilidade da instância criadora em relação à coisa criada (...) Essa escolha ética não emana de uma enunciação transcendente, de um código de lei, mas do próprio movimento de criação" (Costa, 1994, p. 13), que precisa ser cultivado, respeitado.

Como é atual, assim me parece, a defesa que desde os anos trinta Anísio faz do diálogo da ciência com a arte! Tanto a liberdade de pensamento quanto a liberdade de criação apontam para uma escola que desestabilizada no seu papel de agência de controle e punição social se torne um ateliê de todos os talentos humanos. Um ateliê no qual se pratique uma disciplina na qual ocorra, como dizia Augusto Rodrigues, “(...) a junção de todas as forças no sentido de ordená-las. Portanto, disciplina em função (...) da obra feita. Não é só olho. É mão, é tudo. Até os poros do corpo em função, em equilíbrio (...) uma disciplina em que a gente esteja com tal acuidade que não atente contra o material que estamos trabalhando, e que o material nos diga também o que 
podemos fazer" (1983, p. 48-49). Confesso que essa forma de entender a disciplina me agrada quando penso no pesquisador. Não prescindimos do rigor teórico, mas ousamos com a nossa imaginação. Comprometemos a nossa fidelidade exclusivamente à construção dos nossos objetos e à sua necessidade social. Assim compreendo, com Anísio, a pesquisa como apreensão criativa do mundo, a pesquisa como modo de educar e de educar-se.

Nesse ponto, o pensamento de Anísio antecipa e se aproxima da tematização do diálogo em Paulo Freire. A meta ainda é a maioridade do povo brasileiro, não só pela valorização da cultura popular, mas também pela sua transformação em instrumento efetivo de construção da sua autonomia, entendida como um valor da educação.

Celebrar Anísio Teixeira, nesta oportunidade, é advertir para quem estiver atento e exercitando uma escuta sensível, que os homens capazes de manter o desejo pela educação por toda uma vida, como ele o fez, apesar das rupturas que as circunstâncias lhe impuseram, são imprescindíveis e, hoje, cada vez mais raros. O principal é o motivo e o principal, como diz Clarice Lispector, está sempre escondido.

A obra de Anísio Teixeira é resultado da eleição da educação como foco de trabalho. Sua motivação em torno desse foco torna-se um campo de significados justamente pela sua persistência. Um homem apaixonado, como afiança Augusto Rodrigues, "não está doente, apenas acelera o seu processo interno" (Idem, ibidem). A paixão não se explica. Vive-se! A obra de Anísio Teixeira é a defesa apaixonada da educação. Mas não apenas isso. É, como afirma Florestan Fernandes, uma defesa polida por uma filosofia da educação e uma compreensão aguda da história da nossa sociedade. Uma defesa iluminada pela sua imaginação pedagógica (1992). A obra de Anísio e de seus companheiros, como nos ensinou Antonio Candido (1980) não foi revolucionária, mas expressão de um pensamento radical, que operou um significativo deslocamento para a frente, na direção da solidariedade e da justiça social. E isto precisa ser reconhecido e valorizado.

Entre o passado de Anísio e o nosso presente há sucessivas camadas de pensamento que se interpõem e que de formas diferentes e variadas acolheram o que pensou, escreveu e concretizou em obras que se apresentam, ainda, à frente do nosso próprio tempo. $O$ Anísio que se torna referência está entre nós! Ele joga luz na sombra de uma geração que o sucedeu e que ainda se debate num país subdesenvolvido, mas o que é importante, ainda num país em construção. E, como vociferou Celso Furtado, em entrevista recente, um país em construção não pode ser entregue ao mercado (Furtado, 2000, p. 7). O Anísio que está, nesse momento, entre nós não pretende cicatrizar feridas, mas reabri-las quando um falso conforto vem mascarar a nossa dor. Este estar entre revela o trânsito em que todos estamos, viajantes do mundo, ambíguos e incompletos, enfrentando a ausência de projetos, a carência de utopias, a constante necessidade de relativização da tarefa pedagógica e do exercício do humano. Este estar entre costura e descostura os fragmentos que vivemos e somos.

Anísio já não é mais árvore, como pretendia, quando escreveu a Monteiro Lobato falando da secura feliz de apenas existir, sem mais nada desejar (Vianna \& Fraiz, 1986, p. 87). Anísio é rizoma. Espalha-se numa simultaneidade de rostos inventados a cada decisão que o acolhe. Ao mesmo tempo, escapa. Sempre: escolanovista, tecnicista, americanista, liberal, conservador, pioneiro, visionário, romântico, iluminista, comunista, reacionário.

Escapa Anísio, que és somente miragem, fragrância, estremecimento!

Volta Anísio! Volta: na poesia que reaparece como esperança após cada fracasso; na exigência de uma fraternidade que não se debruce no vazio, mas eleja como alvo nossas relações concretas no cotidiano; no resgate da memória e da história da nossa sociedade e da nossa educação; na generosa militância da cultura e no exercício digno da política; no diálogo da ciência com a arte; em projetos de educação que integrem a cultura e o trabalho. Volta na força que nos move na defesa de que a educação não é privilégio!

A obra de Anísio Teixeira é a sua própria vida. Para além dos elogios e das celebrações, o convívio com ela me ensina que, ao procurar desvendá-la, acabamos falando um pouco de nós mesmos. Corremos o risco de sucumbir à presunção e à arrogância, reduzindo e 
engessando o processo que vai da intimidade do sujeito à construção da ordem social. É necessário um laborioso investimento para nos libertarmos da couraça acadêmica que nós próprios construímos, tornando a existência sem brilho. O saber ilumina, mas a vida é tato.

Anísio Teixeira está entre nós! Não exatamente nas minhas palavras, ou nas nossas palavras, mas em algum ponto secreto e ignorado das nossas próprias consciências, na vibração sutil que nos move. Provavelmente no silêncio fecundo que em nós habita e que irradia dos nossos corações de educadores.

CLARICE NUNES doutorou-se em Ciências Humanas/Educação pela PUC-Rio. Professora titular em História da Educação, na Faculdade de Educação da UFF (aposentada). Atualmente vincula-se como pesquisadora ao Programa de Pós-Graduação em Educação dessa Universidade e é professora no Mestrado em Educação da Universidade Estácio de Sá. Autora de livros, artigos, ensaios e publicações técnicas na área de História da Educação, destacando-se como produção mais recente: verbete sobre Anísio Teixeira, no Dicionário de educadores no Brasil (EdUFRJ e INEP, 1999), Anísio Teixeira. A poesia na ação (Ed. USF, 2000) e colaboradora na coletânea 500 anos de educação brasileira, com o ensaio "(Des)encantos da modernidade pedagógica”. E-mail: claricenunes@openlink.com.br

\section{Referências Bibliográficas}

ANDRADE, Carlos Drummond, (1983). Entrevista ao programa "Depoimentos" da Fundação Candido Portinari, realizada em 20/11/ 1983. Fundação Candido Portinari. Rio de Janeiro: PUC-Rio.

CANDIDO, Antonio, (1980). Teresina e etc. Rio de Janeiro: Paz e Terra.

COSTA, Mauro José Sá Rêgo, (1994). O artista na sala de aula: outras perspectivas para a educação artística. Tese de Doutorado, Rio de Janeiro: UFRJ.

DEJOURS, Christophe, (1999). A banalização da injustiça social. Rio de Janeiro: Editora da FGV.

FERNANDES, Florestan, (1992). Anísio Teixeira e a luta pela escola pública. In: ROCHA, João Augusto de Lima, (org.). Anísio em movimento: a vida e as lutas de Anísio Teixeira pela escola pública e pela cultura no Brasil. Salvador: Fundação Anísio Teixeira.

FILHO, Lourenço. Correspondência entre Anísio Teixeira e Lourenço Filho. Arquivo Anísio Teixeira, série correspondência, Atc
29.11.01, documento n. 15, Carta de Lourenço Filho a Anísio Teixeira em 31/1/1935, CPDOV, FGV.

Parecer Crítico. Introdução ao estudo da escola nova. Arquivo Lourenço Filho, série Produção Intelectual, LF/S Ass. Pi 30/32.00.00, CPDOC/FGV.

FURTADO, Celso, (2000). O Brasil em ruínas. Valor, p. 7, jun.

GONZAGA TEIXEIRA, Luiz, (2000). O discurso que faz o elogio da pedagogia. São Roque-SP, mimeo.

LAGOA, Ana Mascia, (1995). Sous-venir de classe (memórias do curso Política de Formação de Professores). Rio de Janeiro, mimeo.

LEMME, Paschoal, (1988). Memórias. São Paulo: Cortez/INEP, v. 2 e 3 .

MENEZES, Sebastião. Carta a Filinto Müller em 8/2/1938. Arquivo Filinto Müller, série Chefatura de Polícia do DF, FM 33.02.21 cph/ad, doc. II-52, CPDOC/FGV.

NUNES, Clarice, (2000). A poesia da ação. Bragança Paulista-SP: EDUSF.

,(1999). Anísio Teixeira (verbete). In: Maria de Lourdes de Albuquerque Fávero e Jader de Medeiros Britto. Dicionário de Educadores no Brasil; da colônia aos dias atuais. Rio de Janeiro: Editora UFRJ/INEP, p. 56-64.

, (1994). Prioridade número um para a educação popular. In: TEIXEIRA, Anísio. Educação não é privilégio. 5. ${ }^{\mathrm{a}}$ ed. Rio de Janeiro: Editora da UFRJ.

RIBEIRO, Darcy Ribeiro, (1978). UnB: invenção e descaminho. Rio de Janeiro: Avenir Editora Ltda.

RIBEIRO, Renato Janine, (1987). Posfácio. In: Carlo Ginzburg. $O$ queijo e os vermes. São Paulo: Companhia das Letras.

RODRIGUES, Augusto, (1983). Entrevista ao Programa "Depoimentos" da Fundação Candido Portinari, realizada em 19/10/1983. Fundação Candido Portinari. Rio de Janeiro: PUC-Rio.

SALMERON, Roberto, (1999). A universidade interrompida; Brasília 1964-1965. Brasília: Editora da UnB.

SILVA, Tomaz Tadeu da, (1996). O projeto educacional da "nova" direita e a retórica da qualidade total. Universidade e Sociedade, ano 6 , n. 10 , jan.

TEIXEIRA, Anísio. Comentários sobre a introdução ao estudo da 
escola nova. Arquivo Anísio Teixeira, série Produção Intelectual, AT Teixeira A pi 20/30.00.00/1, CPDOC, FGV

Manuscrito de um programa de partido político. Arquivo Anísio Teixeira, série Produção Intelectual, AT [Teixeira, A] pi 37/46.00.00, CPDOC/FGV

. Esboço de um trabalho distinguindo a função dos políticos e pensadores de um lado e dos técnicos de outro, dentro da atividade educacional nacional. Arquivo Anísio Teixeira, série Produção Intelectual, AT [Teixeira, A] pi 00.00.00/17, CPDOC/FGV.

TEIXEIRA, Anísio, (1969). Educação no Brasil. São Paulo: Editora Nacional.

VIANNA, Aurélio e FRAIZ, Priscila, (1986). Conversa entre amigos; correspondência escolhida entre Anísio Teixeira e Monteiro
Lobato. Cartas entre Monteiro Lobato e Anísio Teixeira, em 19/7/ 1941; 1/1/1947 e 29/1/1947. Salvador, FC do Estado da Bahia; Rio de Janeiro: FGV/CEPDOC.

VIDAL, Diana Gonçalves, (org.), (2000). Na batalha da educação: correspondência entre Anísio Teixeira e Fernando de Azevedo (1929-1971). Bragança Paulista: EDUSF. (Cartas de Anísio Teixeira a Fernando de Azevedo em 20/4/1940; 15/2/1960; 18/1/ $1971 ; 4 / 2 / 1971$.

WARDE, Miriam Warde, (1984). Liberalismo e educação. Tese de doutorado, PUC-SP.

ZANTEN, Agnés van e BALL, Stephen, (2000). Comparer pour comprendre: globalisation, réinterprétations nationales et recontextualisations locales des politiques éducatives néolibérales. Revue de l'Institut de Sociologie. Bruxelles, p. 1-20, mimeo. 